Received: June 9, 2017

\title{
Study on the problems and countermeasures of efficient legal practice education based on the cultivation of citizen consciousness*
}

\author{
Haiying Zheng ${ }^{1}$ \\ Beihua University
}

\author{
Xiufen Xing ${ }^{2}$ \\ Beihua University
}

\begin{abstract}
Since the 21st century, the legal practice education of college students in China has gradually transferred the focus from the popularization of legal knowledge to the cultivation of citizen consciousness. Law education is practical education instead of theoretical education. Under the vision of cultivation of citizen consciousness, this study explores the problems of college students' efficient legal practice education, and puts forward some solutions to the existing problems. The results show that the subject of legal practice education under the system of cultivation of citizen consciousness is college students whose depth of legal consciousness is not enough. The legal practice education can also actively arouse the enthusiasm of students, strengthen students' ability of coping with psychological quality and solving problems, and cultivate college students' consciousness and citizen consciousness. This study provides theoretical basis for promoting the legal practice education of college students and cultivating the citizen consciousness of college students.
\end{abstract}

\section{Keywords}

Legal Practice Education • Citizen Consciousness • Theoretical Education • Psychological Quality

\footnotetext{
"This work was supported by construction of community legal clinic education of the 13th five-year plan project of education science in Jilin province (No. GH170111).

${ }^{1}$ College of law, Beihua University, Jilin 132000, China. Email: jlzhenghy@ beihua.edu.cn

${ }^{2}$ Correspondence to: Xiufen Xing. College of law, Beihua University, Jilin 132000, China. Email: lxingxf@ beihua.edu.cn

Citation: Zheng, H. Y., Xing, X. F. (2018). Study on the problems and countermeasures of efficient legal practice education based on the cultivation of citizen consciousness. Educational Sciences: Theory \& Practice, 18(5), 1932-1939. http://dx.doi.org/10.12738/estp.2018.5.092
} 
Citizen consciousness formation is to make citizens know their subject status in society, clarify their legal status in society, and recognize the relationship between citizens. Mature citizen consciousness and citizen culture is an important symbol of a country's modernization, and is also an important scale for measuring a country's modernization (Magee, 2013). Law education is the most basic modelling factor of a country's legal system. With the continuous improvement of democracy and rule of law, it is irreversible to construct a mature legal system. The formation of citizen consciousness can promote the progress and harmony of modern society. The cultivation of citizen consciousness includes law education, political education and moral education of citizen (Gurpur \& Rautdesai, 2014, Rhinode, 2013). In the modernization construction of rule of law, efficient legal practice education has become an important part of citizen's law education. In particular, the law education of college students has a special status and function in the cultivation of citizen consciousness. The cultivation of citizen consciousness of college students and legal practice education supplement each other (Jensen et al., 2015). At present, there is deviation in the concept of legal practice education and there are great defects in the modes and contents of popularization of law. The way of practice education is too monotonous, and there is no practical effect in the wanton writing publicity (Arias \& Faltis, 2013).

In recent years, as people pay attention to ideological cultivation, people's way of legal practice education has been constantly perfected and the law education of college students has become an important way to cultivate citizen consciousness (Yasmin, 2012). Citizen consciousness is an important index to measure national quality and socialist modernization. The legal practice education under the cultivation of citizen consciousness has the value of the times (Farias-Sokoloski, 2014). Efficient legal practice education under the cultivation of citizen consciousness can promote the growth of college students, as well as help college students to form legal beliefs and to actively participate in the process of legal construction so as to form citizen consciousness with effects of infection, promotion and restriction (Prestonshoot, Mckimm, Kong \& Smith, 2011). Under the vision of cultivation of citizen consciousness, this study explores the problems of college students' efficient legal practice education, and puts forward some solutions to the existing problems.

\section{Value creation and realization of legal practice education}

Law education provides citizens with subject consciousness, equal consciousness, contract idea, democratic thought and power obligation idea, which is the indispensable cultural foundation and value support in the construction of citizen culture. There are various forms of citizen's legal practice education. By improving citizen's law education, we should cultivate citizen's consciousness, improve citizen's legal quality comprehensive way and strengthen legal practice education, which is related to social stability and healthy development (Hammer, Chardon, Collins \& Hart, 2012). Legal practice education is extensive, equal and multilevel, and the essence of its educational value creation is the promotion of citizen consciousness and the bridging of object. Its significance lies in the transformation and sublimation of citizen concept to provide a new value orientation and provide conditions for the value orientation of society as a whole (Babacan \& Babacan, 2017). The subject of practical education integrates the ready-made existence of education object with the need of subject through decision-making consciousness, and the value creation of practical education includes three 
aspects: the potential value knowledge of practical education object and instrumental elements formed by the subject of practical education, the construction of value relationship and the realization of value existence.

Legal practice education is the basis and intermediate link for determining the value relationship between subject and object, the concept and theoretical innovation of practical education are the prerequisite for the promotion of the value of law education, the innovation of practical education activity is the theme of the value creation of law education, and the innovation of education system and mechanism is the basic guarantee of value creation of law education. The rights and obligations of citizens don't belong to the scope of law, but they can regulate people's behaviors and social relations. The practical function of legal practice education is to endow people with certain rights and corresponding obligations. The most ideal state of cultivation of citizen consciousness is to make law the ultimate goal of citizen's beliefs. It is impossible to carry out legal practice education only through school education, and it is also necessary to strengthen citizen's universal law education and legal practice education. We should emphasize the cultivation of modern legal concept and legal belief, innovate in the form of publicity and expand the influence of education.

\section{Contents of efficient legal practice education under the cultivation of citizen consciousness}

\section{Subject construction of legal practice education under the cultivation of citizen consciousness}

In the college students' law education and legal practice education, both teachers and students directly participate in, and students are always on the front line of learning knowledge. The practice of law education is strong. It is the key to build a group of teachers with excellent political, ideological and theoretical qualities to improve college students' law education. At the same time, we need to strengthen teachers' professional teaching abilities and improve teaching and practice quality. The legal practice education of college students is constantly developing, and the contents and forms of practice will also change according to the actual situation, such as visiting and inspecting the education base or other efficient ways. In addition, college students can also practice through legal aid centres and law firms.

Education is the most direct way to promote citizen's legal consciousness, and excellent educators are the most powerful propagandists to strengthen legal practice education. Therefore, colleges and universities should vigorously introduce professional talents with high legal quality and strengthen their faculty of law. Teachers are encouraged to lead students to participate in legal practice education, accumulate relevant experience through the practice process, enrich practical experience of teachers and students, and improve the effect of law education.

\section{Contents of efficient legal practice education under the cultivation of citizen consciousness}

The contents of legal practice education are determined by the expected goals of law education. The practical content determines the practical effect, which is an important guarantee to realize the goal and task of legal 
practice education. First of all, the legal consciousness education of college students should guarantee their learning of the basic legal knowledge, the cognition of common sense of law and the strengthening of the idea of rule of law. Legal practice education is to strengthen citizen's consciousness of legal system. When there are some problems in life, we should strictly act according to law. Citizens shall recognize and deal with the problems in real life according to legal thinking. Affected by social politics, social economy and social culture, citizens will form special feeling and experience to the laws and regulations. Then citizens will cognize the laws and regulations appearing in the society, show their respect and trust to the law from the thought, and gradually cultivate legal cognition, legal emotion, legal will and legal value.

According to different legal standards, law can be divided into substantive law and procedural law according to the practice contents. Procedural law is not the annex of substantive law. The practice process of procedural law is to let citizens learn law to protect their legitimate rights and interests. Different colleges and universities have different legal knowledge requirements on college students, which determine that they master different professional skills. College students, as the subject of cultivation of citizen consciousness, have philosophical, legal and political basis between citizen consciousness and they are interdependent with each other. The cultivation of citizen consciousness is taken as the goal so that the content of college students' law education is more closely related to life, which is more beneficial for college students to subtly accept in practice. The legal consciousness of college students in starting a business and participating in market economy activities is so weak that lawbreaking often happens. In the law education of colleges and universities, we should strengthen the education of laws and regulations on the opposite side of crime.

Through the investigation and research of many colleges and universities, it is found that the constitutional education and practice are not highly popularized in the law education of colleges and universities, and the constitutional education of colleges and universities doesn't embody the spirit of rule of law and the legal value carried by the constitution. The core content and constitutional spirit of constitutional education must be emphasized. To strengthen the constitutional education, we should strengthen right education, power education and belief education. Law education is not a theoretical subject, which pays attention to practice. If we want to transform from legal knowledge to legal ability, we must make use of legal practice and highlight legal practice education. Guided by the legal practice education, the legal knowledge learned by college students will be continuously applied to life and learning so as to improve law usage ability of college students in the teaching process. Strengthening the legal practice education of college students can promote college students to change from law abidance to law ability, and use legal weapons well in practice. Legal practice education can also actively arouse students' enthusiasm, enhance students' ability to deal with psychological quality and solve problems, and truly cultivate college students' consciousness and citizen consciousness.

\section{Problems and reasons of college students' legal practice education}

\section{Problems and reasons of college students' legal practice education}

The questionnaires on many college students show that college students have legal theory, but the effect of 
practical education is not ideal, which is mainly reflected in that the legal knowledge system of college students is complete, but the degree of recognition to the law is not high; they won't use law to regulate their own behaviors; crimes of college students happens every year; the importance of the law isn't known enough. At present, the problems existing in the law education of college students are as follows. The effect of law education is not ideal, the educational curriculum is not reasonable, the educational method lacks innovation and the educational practice link is weak. Law exists and is learnt in practice, and the practice of law education is very strong. Only by combining theory and practice can college students cultivate their ability of law usage and promote the implementation of law education. Moreover, too much emphasis is placed on the education of abstract legal theory, the textbook can't fully reflect the latest legal norms, the content of education emphasizes too much on obligations but neglects rights, the method of law education is single, and the practical link is relatively weak.

Since the 21 st century, college students' legal practice education has gradually shifted the focus from popularizing legal knowledge to citizen consciousness formation, and college students' participation consciousness has provided better social and historical conditions, scientific and technological conditions and basis for citizen consciousness formation. The foreign legal practice education is rich in content and the educational idea is clear. The legal practice education way is diversified, mainly focusing on internship and service learning. Thus, the citizen's democratic value belief and the legal practice skill are greatly improved. Law is an important guarantee of perfecting college students' legal study, and the problems existing in college students' legal practice education include little attention to law education laid by educators and college students and lack of professional teachers. China's colleges and universities didn't open the "legal basis" curriculum until 1987. The law education of college students just goes into the stage of legal awareness education, and the time of popularization of law is short.

\section{Measures for perfecting college students' legal practice education}

In term of contents and goals, that citizen consciousness formation is highly consistent with the legal practice education. China pays more and more attention to the popularization of law for college students, and the formation of the legal accomplishment of student group is the key to the cultivation of legal consciousness of the whole people. Through the study of foreign legal practice education, we should establish scientific educational idea, implement and expand diversified educational ways, and enrich educational contents. In addition, we should take measures to perfect the legal practice education of college students:

First, we shall strengthen popularization of law and create a good campus environment. We should use new media to strengthen popularization of law to provide a good legal environment for college students. Besides, we can make use of legal festivals to strengthen popularization of law, open legal forums and thematic activities, or organize participation in public legal voluntary activities.

Second, we will give full play to the leading role of classroom teaching. We shall reasonably plan law education and legal practice time, increase the legal practice time appropriately, enrich practice contents, and 
pertinently add practice projects according to different majors of college students. The teaching methods of law education shall be improved to adopt appropriate methods for college students' law education and legal practice education. Furthermore, case teaching method, discussion teaching method and multimedia teaching method will be used to actively guide students to participate in legal practice activities.

Third, we will increase legal practice activities and promote the combination of learning and doing. The legal practice education activities don't need to stick to the form, but shall determine the corresponding practice projects combined with majors. The school can set up a special legal service department to solve the difficult legal knowledge in students' study, solve the problems in students' life, and reduce the fraud or pyramid sale of social lawbreakers received by students. Moreover, we can make use of student associations to carry out practical activities or organize students to participate in internship in the judicial departments, encourage students to actively engage in law enforcement activities of judicial administrative departments, and organize students to practice in the judicial departments. In addition, we will strengthen the process of judicial administrative law enforcement of students, cultivate the legal accomplishment of college students, and urge them to form good citizen consciousness.

\section{Conclusions}

Under the vision of cultivation of citizen consciousness, this study discusses the problems of college students' efficient legal practice education, and puts forward some solutions to the existing problems. The concrete conclusions are as follows:

(1) Education is the most direct way to promote citizen's legal consciousness, and excellent educator is the most powerful propagandist to enhance legal practice education. College students, as the subject of cultivation of citizen consciousness, can accumulate relevant experience through practice process, enrich their practical experience and improve the effect of law education.

(2) The practice of law education is very strong. Only by combining theory and practice can college students cultivate their ability of law usage. The law education of college students shall be put into practice, and the cultivation of citizen consciousness of college students shall be improved by strengthening popularization of law, giving full play to the leading role of classroom teaching and increasing legal practice activities.

\section{References}

Arias, M. B., \& Faltis, C.J. (2013). Implementing educational language policy in Arizona. International Journal of Bilingual Education \& Bilingualism, 16(6), 757-761. http://dx.doi.org/10.1080/13670050.2012.747480

Babacan, A., \& Babacan, H. (2017). Enhancing civic consciousness through student pro bono in legal education.

Teaching in Higher Education, 22(6), 1-18. http://dx.doi.org/10.1080/13562517.2016.1273210 
Borde, P., Varpe, A., Manza, R., Yannawar, P. (2015). Recognition of isolated words using Zernike and MFCC features for audio visual speech recognition. International Journal of Speech Technology, 18(2), 167-175. https://link.springer.com/article/10.1007/s10772-014-9257-1

Christiansen, T. (2011). Fluency and pronunciation in the assessment of grammatical accuracy in spoken production: An empirical study an empirical study. Journal of Biological Chemistry, 286(39), 33795-33803.

Cooke, M., Barker, J., Cunningham, S., Shao, X. (2006). An audio-visual corpus for speech perception and automatic speech recognition. Journal of the Acoustical Society of America, 120(5-1), 2421-2424.

Espy, W. C. (2005). Automatic speech recognition. Journal of the Acoustical Society of America, 117(4), 24032403.

Farias-Sokoloski, T. (2014). Implementing educational language policy in Arizona: Legal, historical and current practices in SEI, by m. Beatriz Arias and Christian Faltis. Bilingual Research Journal, 37(2), 211-213. http://dx.doi.org/10.1080/15235882.2014.934486

Furoh, T., Fukumori, T., Nakayama, M., Nishiura, T. (2013). Detection for Lombard speech with second-order Mel-frequency cepstral coefficient and spectral envelope in beginning of talking-speech. Journal of the Acoustical Society of America, 133(1), 3246.

Gonçalves, J. P., Aluisio, S. M., Oliveira, L. H. M. D., Jr, O. N. O. (2004). A learning environment for English for academic purposes based on adaptive tests and task-based systems. Lecture Notes in Computer Science, 3220, 1-11.

Gurpur, S., \& Rautdesai, R. (2014). Revisiting legal education for human development: best practices in south asia. Procedia-Social and Behavioral Sciences, 157, 254-265. http://dx.doi.org/10.1016/j.sbspro.2014.11.028

Hammer, S. J., Chardon, T., Collins, P., \& Hart, C. (2012). Legal educators' perceptions of lifelong learning: conceptualisation and practice. International Journal of Lifelong Education, 31(2), 187-201. http://dx.doi.org/10.1080/02601370.2012.663803

Hieronymus, J., Kadambe, S. (1997). Robust spoken language identification using large vocabulary speech recognition. Journal of Membrane Science, 2(1), 1111-1114. https://doi.org/10.1109/MASS.1995.528223

Jensen, K., Nerland, M., \& Enqvistjensen, C. (2015). Enrolment of newcomers in expert cultures: an analysis of epistemic practices in a legal education introductory course. Higher Education, 70(5), 1-14. http://dx.doi.org/10.1007/s10734-015-9872-z

Kewleyport, D., Dalby, J., Burleson, D. (2002). Speech intelligibility training using automatic speech recognition technology. Journal of the Acoustical Society of America, 112(5), 2303. http://dx.doi.org/10.1121/1.4779274

Magee, R. V. (2013). Contemplative practices and the renewal of legal education. New Directions for Teaching \& Learning, 2013(134), 31-40. http://dx.doi.org/10.1002/t1.20052

Prestonshoot, M., Mckimm, J., Kong, W. M., \& Smith, S. (2011). Readiness for legally literate medical practice? student perceptions of their undergraduate medico-legal education. Journal of Medical Ethics, 37(10), 616-622. http://dx.doi.org/10.1136/jme.2010.041566

Qi, Y., Dong, B., Ge, F., Yan, Y. (2012). Text-independent pronunciation quality automatic assessment system for English retelling test. Journal of the Acoustical Society of America, 131(4), 3234. 
http://dx.doi.org/10.1121/1.4708063

Rhode, D. L. (2013). Reforming American legal education and legal practice: Rethinking licensing structures and the role of nonlawyers in delivering and financing legal services. Legal Ethics, 16(2), 243-257. http://dx.doi.org/10.5235/1460728X.16.2.243

Song, Z., Liu, B., Pang, Y., Hou, C., Li, X. (2012). An improved Nyquist-Shannon irregular sampling theorem from local averages. IEEE Transactions on Information Theory, 58(9), 6093-6100. https://doi.org/10.1109/TIT.2012.2199959

Thomas, I. B., Ravindran, A. (1971). Preprocessing of an already noisy speech signal for intelligibility enhancement. Journal of the Acoustical Society of America, 49(1), 133.

Villchur, E. (1973). Signal processing to improve speech intelligibility in perceptive deafness. Journal of the Acoustical Society of America, 53(6), 1646-1657. https://doi.org/10.1121/1.1913514

Wang, L., Qian, Y., Scott, M. R., Chen, G. (2012). Computer-assisted audiovisual language learning. Computer, 45(6), 38-47. https://doi.org/10.1109/MC.2012.152

Xing, Z., Yong, Q., Pang, X., Jia, L., Yuan, Z. (2010). Modelling of the automatic depth control electrohydraulic system using RBF neural network and genetic algorithm. Mathematical Problems in Engineering, 4, 242256.

Yasmin, T. (2012). International practice of public legal education: a missing element in the justice system of bangladesh. Commonwealth Law Bulletin, 38(3), 467-483. http://dx.doi.org/10.1080/03050718.2012.694998

Zechner, K., Higgins, D., Xi, X., Williamson, D. M. (2009). Automatic scoring of non-native spontaneous speech in tests of spoken English. Speech Communication, 51(10), 883-895. https://doi.org/10.1016/j.specom.2009.04.009 